\title{
Development of High Protein Populations of Maize (Zea mays L.) From Three Cycles of Reciprocal Recurrent Selection
}

\author{
${ }^{1}$ Emmanuel Okporie, ${ }^{1}$ Samuel Chukwu and ${ }^{2}$ Godwin Onyishi \\ ${ }^{l}$ Department of Crop Production and Landscape Management, Ebonyi State University, Abakaliki, Nigeria \\ ${ }^{2}$ Department of Crop Science and Technology, Federal University of Technology, Owerri, Nigeria
}

\begin{abstract}
This breeding programme was initiated at the Department of Crop Production and Landscape Management's teaching and research farm of the Ebonyi State University, Abakaliki. The genetic materials were sourced from the University of Nigeria gene bank. After three cycles of reciprocal recurrent selection, two high protein populations of maize (Zea mays L.) with mean protein content estimates of 14.4 Nsukka High Protein - Early $(N H P-E)$ and 14.3 Nsukka High Protein - Late $(N H P-L)$ were developed from populations with average protein contents of 7.6 and 8.6 per cent, respectively. The new populations can be used as commercial varieties, as parents in varietal crosses or as reservoirs of germplasm for further improvement and extraction of superior inbred lines for use in hybrid maize production.

Key Words: Maize, Protein, Reciprocal recurrent selection, Selection cycles
\end{abstract}

\section{Introduction}

The total protein content of maize grain is highly elastic. Typical maize lines consist of $8-12 \%$ protein, but selection has resulted in a high protein line with over $32 \%$ protein and a low protein line with $4 \%$ protein [1]. Even though high protein is possible in maize, selection for yield has increased starch and decreased total protein [2]. The World Health Organization estimated the prevalence of underweight preschool children in 2010 was $16.2 \%$ percent (103.7 million). The prevalence was $4.3 \%$ in Central America and $19.3 \%$ in Africa (1.8 and 30.3 million respectively) [3,4], both including areas like Nigeria where maize is a staple crop. When inadequate protein intake is combined with adequate carbohydrate consumption over a long period of time, there is decreased synthesis of visceral proteins, including albumin. This results in a decrease in hydrostatic pressure in the vascular system and extravascular fluid accumulation under the skin and in body cavities [5]. Other measures of malnutrition are stunting (low height for age) and wasting (low weight for height). In sub-Saharan Africa, it is estimated that $10 \%$ of children are wasting and stunting can be as high as $40 \%$ in some areas as a result of low protein consumption [6].

Recurrent selection is one of the most simple ways to improve a trait, if there is a straightforward way to quantify the trait of interest and a population with heritable variation for the trait [7]. Recurrent selection is simply the selection for a certain trait or traits over many generations, and can be used to control complex multigenic traits. It results in combinations of genes in a genetic background that directly influence a phenotype. Reciprocal recurrent selection is one of the most effective breeding methods for developing improved commercial varieties. It is designed to increase the frequency of desirable alleles for quantitative traits in breeding populations as well as the maintenance of genetic variability for further improvement $[8,9]$. The objectives of the study were to develop maize populations of enhanced protein content and to develop reservoirs of germplasm highly suitable for the extraction of superior inbred lines for use in hybrid maize production.

\section{Materials And Methods}

This breeding programme was initiated at the Department of Crop Production and Landscape Management's teaching and research farm of the Ebonyi State University, Abakaliki (Longitude $08^{0} 03^{1} \mathrm{E}$ and Latitude $06^{0} 25^{1} \mathrm{~N}$ ) [10]. The genetic materials were sourced from the University of Nigeria gene bank [11]. Two open-pollinated early maturing maize varieties, NHP-WE and NHP-YE, represented populations "A" while two open-pollinated late-maturing varieties, namely NHP-WL and NHP-YL represented populations "B". The populations were coded $\mathrm{A}^{1}, \mathrm{~A}^{2}$ and $\mathrm{B}^{1}, \mathrm{~B}^{2}$. These seeds were used for three cycles of reciprocal recurrent selection starting from 2002 to 2011 with three planting seasons per cycle. After each cycle, the seeds were preserved properly at 15.5 per cent moisture content in the gene bank of the Ebonyi State University, Abakaliki. The procedure for reciprocal recurrent selection as outlined by Obi and Onyishi [8] was adopted.

\section{First planting season (inter-cross stage)}

The experimental plot was $5.25 \times 26.25 \mathrm{~m}^{2}$ with row length of $2.50 \mathrm{~m}$ and comprising ten plants each. The plant spacings were $25 \mathrm{~cm}$ within rows and $75 \mathrm{~cm}$ between rows at one plant per hill, giving a plant 
population 53, 333 plants per hectare. The $25 \times 75 \mathrm{~cm}$ spacing was maintained in all the planting seasons that the study lasted.

\section{Selfing and cross pollination procedure}

Fifteen plants each of populations $\mathrm{A}^{1}$ and $\mathrm{A}^{2}$ were self-pollinated, and each selfed plant was used as a male to cross to different randomly selected plants from populations $\mathrm{B}^{1}$ and $\mathrm{B}^{2}$, respectively. A similar procedure was followed to obtain selfed plants in " $\mathrm{B}$ " populations and associated test crosses to " $\mathrm{A}$ " populations. During this hybridization, the tassel - bag - shoot - bag method of hand pollination as described by Okporie and Obi [9] was used to self individual maize plants and also in cross pollinating other plants. Maize cobs were harvested when the plants had completely senesced and seeds had reached physiological maturity using black layer formation as an index of maturity [12]. Selfed seeds $\left(\mathrm{S}_{1}\right)$ were stored in a refrigerator for later use.

\section{Second plating season (evaluation stage)}

The experiment was laid out in a Randomized Complete Block Design (RCBD) with three replications. The sets of test crosses from populations "A" and "B" were grown in performance trials and the seeds analysed for protein content. The $\mathrm{S}_{1}$ lines were selected at $10 \%$ selection intensity which corresponded to a standardized selection differential of $1.76[13,8]$.

\section{Third planting season (recombination stage)}

The experimental plants were established using the standard plant spacings of $25 \times 75 \mathrm{~cm}$ within and between rows, respectively, and the $S_{1}$ selected lines were allowed to recombine by mating the selected lines in all possible combinations. Equal quantities of the recombinant seeds were bulked to form the new populations used as tester parents in the second cycle of the programme. The seeds of the recombinants were analysed for per cent crude protein.

\section{Fourth, fifth, sixth, seventh, eighth and ninth planting seasons}

The procedures used in the first cycle of the reciprocal recurrent selection were repeated in the second and third cycle. At the end of the third cycle, populations $\mathrm{A}^{1}$ and $\mathrm{A}^{2}$, and $\mathrm{B}^{1}$ and $\mathrm{B}^{2}$ were bulked separately to form the two high protein synthetics or populations.

\section{Protein determination}

The crude protein of the maize samples was determined by the Micro - Kjeldahl method as described by Pearson [14]. Percent protein was calculated as N\% x 6.25. Data on all agronomic characteristics including protein content were analysed according to Randomised Complete Block Design (RCBD) analysis of variance procedures as described by Obi [15] and Okporie [16]. Fisher's least significant difference (F-LSD) was used to compare differences between means after the preliminary F-test $[17,16]$. A t-test was used to compare differences between the original and derived populations.

\section{Results}

The result of crude percentage protein of the populations (synthetic) for first cycle, second and third cycles in each of the four source populations is as presented in Table 1. The protein content of the open pollinated maize varieties was pushed from $10.12 \%$ for population $\mathrm{A}^{1}, 5.08 \%$ for population $\mathrm{A}^{2}, 10.34 \%$ for population $\mathrm{B}^{1}$ and $6.83 \%$ for population $\mathrm{B}^{2}$ of the original populations (Table 1) to $11.79 \%, 10.80 \%, 11.30 \%$ and $11.88 \%$ for populations $A^{1}, A^{2}, B^{1}$ and $B^{2}$, respectively of the first cycle populations. These were further pushed up to $13.00 \%, 13.00 \%, 13.26 \%$ and $13.10 \%$ for populations $\mathrm{A}^{1}, \mathrm{~A}^{2}, \mathrm{~B}^{1}$ and $\mathrm{B}^{2}$ respectively of the second cycle populations. After the third cycle, the populations further responded to selection by $14.58 \%, 14.12 \%$, $14.61 \%$ and $14.06 \%$ for $\mathrm{A}^{1}, \mathrm{~A}^{2}, \mathrm{~B}^{1}$ and $\mathrm{B}^{2}$, respectively.

The mean protein content of the parents was $13.09 \%$ while their progenies had percentage protein content of $14.35 \%$, showing an increase of $1.26 \%$ (Table 1). The mid parent heterosis was $9.63 \%$. The result showed significant improvement in protein content after the first, second and third cycles of the breeding programme (Table 3). With regards to the percentage increase after the first cycle $\left(\mathrm{C}_{0}-\mathrm{C}_{1}\right)$ range from 9 to 113 per cent, $\left(\mathrm{C}_{0}\right.$ $\left.-\mathrm{C}_{2}\right)$ from 27 to 156 per cent and $\left(\mathrm{C}_{1}-\mathrm{C}_{2}\right)$ from 10 to 22 per cent after the second cycle of the programme. The per cent increase in protein after the third cycle $\left(C_{0}-C_{3}\right)$ range from 42 to 106 per cent, $\left(C_{1}-C_{3}\right)$ from 18 to 31 per cent and $\left(\mathrm{C}_{2}-\mathrm{C}_{3}\right)$ from 7 to 12 per cent.

Despite the increased protein, the early-maturing varieties, populations $\mathrm{A}^{1}$ and $\mathrm{A}^{2}$ maintained their early maturing attaining 50 per cent silking in less than 60 days from the date of planting, while the late-maturing varieties, populations $\mathrm{B}^{1}$ and $\mathrm{B}^{2}$ maintained their late maturing attaining 50 per cent silking at 60 days and above suggesting no relationship between protein and time of maturity (Tables 1 and 2). However, some of the 
variations observed among the populations especially in 100-seed weight (g), kernel density $(\mathrm{g} / \mathrm{cc})$ and days to $50 \%$ silking were not evaluated.

Table 1: Yield characteristics of the populations (synthetics) of high protein after the first, second and third cycles of Reciprocal Recurrent Selection (RRS)

\begin{tabular}{lllll}
\hline & \multicolumn{4}{c}{ Protein (\%) } \\
\cline { 2 - 5 } & $\mathrm{C}_{0}$ & $\mathrm{C}_{1}$ & $\mathrm{C}_{2}$ & $\mathrm{C}_{3}$ \\
\hline NHP-WE $\left(\mathrm{A}^{1}\right)$ & 10.12 & 11.79 & 13.00 & 14.58 \\
NHP-YE $\left(\mathrm{A}^{2}\right)$ & 5.08 & 10.80 & 13.00 & 14.12 \\
NHP-WL (B & 10.34 & 11.30 & 13.26 & 14.61 \\
NHP-YL (B & & 11.88 & 13.10 & 14.06 \\
\hline $\mathrm{C}_{0}=$ Source population & 6.83 & & & \\
$\mathrm{C}_{1}=$ First cycle population \\
$\mathrm{C}_{2}=$ Second cycle population \\
$\mathrm{C}_{3}=$ Third cycle population
\end{tabular}

Table 2: Agronomic characteristics of the populations (synthetics) of high protein after the first, second and third cycles of Reciprocal Recurrent Selection (RRS)

\begin{tabular}{|c|c|c|c|c|c|c|c|c|c|c|c|c|c|c|c|}
\hline & \multicolumn{2}{|c|}{ Plant Haight $(\mathrm{cm})$} & \multicolumn{3}{|c|}{ Ear Haight $(\mathrm{cm})$} & \multicolumn{2}{|c|}{$50 \%$ Silking } & \multicolumn{4}{|c|}{100 - seed Weight $\left(g^{\prime}\right)$} & \multicolumn{4}{|c|}{ KemelDensity $(g c c)$} \\
\hline & $\mathrm{C}_{\mathrm{i}}$ & $C_{2}$ & $C_{1}$ & $C_{0}$ & $\mathrm{C}_{1}$ & $C_{1}$ & $C_{1}$ & $C_{0}$ & $C_{1}$ & C. & $C_{1}$ & $C_{0}$ & $\mathrm{C}_{\mathrm{l}}$ & $c_{1}$ & $C_{1}$ \\
\hline $\begin{array}{cl}C_{0} & C_{4}\end{array}$ & C & $\mathrm{C}$ & & & & & & & & & & & & & \\
\hline NHP.WE $\left(A^{i}\right) \quad 172.3$ & 197.5 & 1968 & 181.3 & 78.9 & 102.0 & 96.1 & 79.3 & 59 & 60 & 59 & $6 !$ & . & 50.93 & 43.80 & 48.60 \\
\hline $0.93 \quad 1.24 \quad 1.13$ & 1.13 & & & & & & & & & & & & & & \\
\hline $\operatorname{NHP} \cdot Y E\left(A^{*}\right) \quad 135.1$ & 147.0 & 167.9 & 196.0 & 53.1 & 61.2 & 74.1 & 95.7 & 58 & 58 & 56 & 58 & . & 46.80 & 46.80 & 46.20 \\
\hline $0.91 \quad 1.21 \quad 1.13$ & 1.12 & & & & & & & & & & & & & & \\
\hline NHP.WL (B') 176.1 & 188.7 & 184.4 & 190.0 & 82.8 & 87.1 & 89.8 & 76.0 & 61 & 63 & 69 & 63 & . & 33.66 & 33.66 & 33.50 \\
\hline $\begin{array}{lll}0.89 & 1.26 & 1.27\end{array}$ & 1.26 & & & & & & & & & & & & & & \\
\hline NHP.YL (B') $\quad 171.3$ & 194.7 & 144.8 & 197.3 & 71.2 & 90.8 & 57.8 & 93.7 & 61 & 61 & 64 & 67 & . & 47.34 & 43.72 & 45.00 \\
\hline $0.97 \quad 1.24 \quad 1.14$ & 1.13 & & & & & & & & & & & & & & \\
\hline $\begin{array}{l}\mathrm{CO}=\text { Original populatic } \\
\mathrm{Cl}=\text { First cycle popula } \\
\mathrm{C2}=\text { Sacond cycle pop } \\
\mathrm{C} 3=\text { Third cycle popu } \\
1(\cdot) \cdot \text { = Data not availab }\end{array}$ & $\begin{array}{l}\text { n } \\
\text { tion } \\
\text { ulation } \\
\text { ation } \\
\text { la dua to }\end{array}$ & & & & & & & & & & & & & & \\
\hline
\end{tabular}


Table 3: Percentage increase of protein from the original populations after the first, second and third cycles of selection

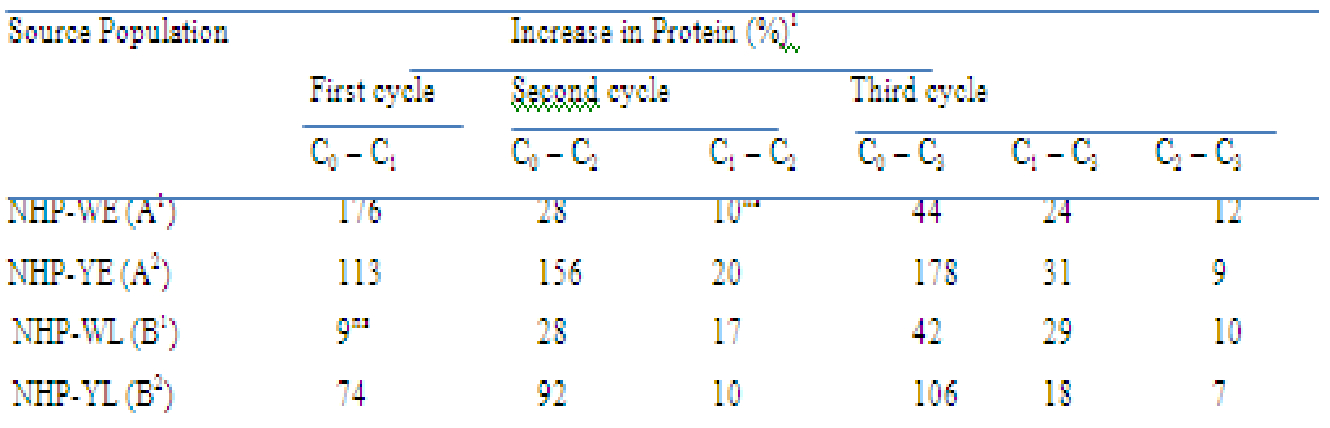

$\mathrm{C}_{0}=$ Original population

$C_{1}=$ First cycle population

$C_{2}=$ Second cycle population

$\mathrm{C}_{\mathrm{S}}=$ Third cycle population

$\mathrm{Ns}=$ Non-significant increase; all other increases are significant

\section{Discussion}

The above results prove the effectiveness of reciprocal recurrent selection as a method in improving both the quality and quantity of protein constituents in maize, and in developing improved maize synthetics. Thus, supporting the favourable dominant gene action as the most important in conditioning heterosis. According to Douglas et al. [18] and Okporie [19], if favourable dominant genes are most important, synthetics should perform progressively more in each cycle than the original populations. But if over-dominance is most important, the synthetics, especially of later cycles, should perform less, not more than the original populations. The increase in protein content led to speculation on the type of gene action that has been most important in conditioning heterosis. The protein content was improved presumably through increase of the frequencies of favourable genes in the populations with selection. Obi and Onyishi [8] and Okporie and Obi [20] pointed out that if recurrent selection methods are effective, the frequency of favourable alleles is expected to increase in the population. At this point in the programme, the data support the favourable dominant gene hypothesis. Selection seems to have been effective in accumulating favourable dominant genes in all the cycles.

The steady response over the three cycles is expected in characters governed by complex systems of genes (quantitative genes) each with small effects on the phenotype. The rate $o f f$ change in frequency for any single gene is expected to be so small that progress toward fixation should be slow, resulting in shift of the population mean $[19,20]$.

The result of this breeding programme corresponds with the report of Obi and Onyishi [8]. Similarly, Deutscher et al. [21] reported an increase in lysine, tryptophan and protein concentrations after five cycles of recurrent selection. Also, Alexander [22] reported an increase from 10 to 32 per cent protein in Illinois High Protein (IHP) recurrent selection programme from 1896 to 1987.

\section{Conclusion}

It is obvious that the recurrent selection procedure adopted is effective in increasing the protein content of the populations used in the study.

\section{Acknowledgements}

The authors wish to acknowledge all researchers round the world whose work were cited in this paper. We also thank all members of staff at the germplasm bank of the University of Nigeria where the germplasm were sourced. Noteworthy to mention here is Professor I.U. Obi for his guidance and encouragements to the authors.

\section{References}

[1]. C. Lucas. Regulation of floury2-mRFP expression in response to long term selection for grain protein concentration in maize: University of Illinois at Urbana-Champaign: 2010, 1-77 p.

[2]. M. Scott, J. Edwards, C. Bell, and J. Schussler. Grain composition and amino acid content in maize cultivars representing 80 years of commercial maize varieties. Maydica: 2006, 417-423. 
[3]. WHO Department of Nutrition for Health and Development. Estimated numbers (in million) of underweight preschool children 1990-2020 with 95\% confidence intervals by UN regions and sub-regions. Department of Nutrition for Health and Development, 2011 a.

[4]. WHO. Estimated prevalence of underweight preschool children 1990-2020 with 95\% confidence intervals by UN regions and subregions. Department of Nutrition for Health and Development, $2011 \mathrm{~b}$.

[5]. N. Scheinfeld, A. Mokashi and A. Lin. Protein-energy malnutrition. Medscape Reference: 2010, pp1-3.

[6]. E. Nuss and S. Tanumihardjo. Quality protein maize for Africa: Closing the protein inadequacy gap in vulnerable populations. Advances in Nutrition 2: 2011, 217-224.

[7]. M. Scott, A. Darrigues, T. Stahly and K. Lamkey. Recurrent selection to alter grain methionine concentration and improve nutritional value of maize. Crop Science 48: 2008, 1705-1713.

[8]. I. Obi and G. Onyishi. Development of high protein populations of maize (Zea mays L.) from two cycles of reciprocal recurrent selection. Samaru J. Agricultural Research, Vol. XI, 1994, pp 63-68.

[9]. E. Okporie and I. Obi. Development of Acid Tolerant, High Yielding and High Nutritional Maize Variety after two years of Mass selection. Sci. Agric, Food Tech and Envirn,. 4: 2004, 23-30.

[10]. E. Okporie, S. Chukwu, G. Onyishi, L. Ekwu, H. Oselebe and E. Utobo. Effects of organic and inorganic manures on growth and yield of fluted pumpkin (Telferia occidentalis Hook.f.) in Abakaliki. Continental J. Agronomy. ISSN: 2141 - 4114. 2012, Pp. 39-49

[11]. G. Onyishi. Development of synthetics of high protein, oil, amylose, amylopectin and low oil maize (Zea mays L.) from two cycles of Reciprocal Recurrent Selection. Unpublished Ph. D thesis submitted to the University of Nigeria. 1992. XV+164pp.

[12]. R. Baker. Black - layer development. World farming 15: 1973, 14 - 19.

[13]. R. Singh and D. Chaudhary. Biometrical methods in Quantitative Genetics Analysis. Kalyani Publishers, Ludhiana, India. 1979, P. 304.

[14]. D. Pearson. The Chemical Analysis of Foods. 7th Edn. Churchill Livingstone Pub. Co. London and New York, 1976 , pp: 575.

[15]. I. Obi. Statistical Methods of Detecting Differences Between Treatment Means and Research Methodology Issues in Laboratory and Field Experiments. $2^{\text {nd }}$ Edition published by AP Express Publishers Ltd, 3 Obollo Road, Nsukka, Nigeria, 2002.

[16]. E. Okporie. Statistics for Agricultural and Biological Sciences.. Cheston Agency Limited Enugu, 2006.

[17]. I. Obi. Statistical methods of detecting differences between treatment means. SNAAP Press, Enugu, Nigeria, 1990, VI + 55pp.

Douglas, J. Collier, M. El.Ebrashu and J. Rogers. An evaluation of three cycles of reciprocal recurrent selection on a corn improvement programme. Crop Science Journal 1: 1961, 157 - 161

[18]. E. Okporie. Development of high quality green maize (Zea mays L.) varieties under acid soil conditions of south eastern Nigeria. Unpublished Ph.D thesis submitted to the Department of Crop science, University of Nigeria, Nsukka, Nigeria, 2000. XV+192

[19]. E. Okporie and I. Obi. Estimation of Genetic gains in protein and oil of eight populations of maize (Zea mays L.) after three cycles of reciprocal recurrent selection. Jour. of Sci. of Agric, Food Tech and Envir. Vol. 2, 2002, pp $40-45$.

[20]. D. Deutscher, M. Zuber, L. Wall and Y. Pomeranz. Effect of selection for lysine concentration in normal maize cultivars. Am. Soc. Abst. 1978, 50.

[21]. D. Alexander. The University of Illinois and Research in corn breeding. Alumni Newsletter, No. 5 Department of Agronomy, University of Illinois, Urbana-Champaign, Illinois, U.S.A. 1987, Pp. 2 - 4. 